\title{
Kualitas Kehidupan Kerja, Kecerdasan Emosi dan Efetivitas Tim Kerja dengan Mediator Komitmen Organisasi
}

Ceria Hermina \& Marcham Darokah

Pusat Layanan Autis Dinas Pendidikan Provinsi Kalimantan Selatan Jl. Perdagangan Kompleks Bumi Indah Lestari 2, 70127 kuin utara \& Fakultas Psikologi ,Universitas Ahmad Dahlan ,Jl. Kapas No.9 Yogyakarta 55166. ceria.hermina@gmail.com

\begin{abstract}
This research identifies the extent of organizational commitment (OC) as mediator variable of quality of work life (QWL), emotional intelligence (EI) and organizational commitment to effective teamwork (ETW) and seeks variables which contribute most to the effective teamwork in the equation models in Nurhidayah Hospital Bantul Yogyakarta. As many as 127 questionnaires were distributed to selected subjects. Data were analyzed by the method of Structural Equation Modeling or SEM using Amos program. The results showed that there is relationship between quality of working life (QWL) and organizational commitment (OC). Quality of working life (QWL) gives 30.5\% contribution on organizational commitment(OC). There is relationship between emotional intelligence (EI) and organizational commitment (OC), emotional intelligence (EI) give 12.5\% contribution on organizational commitment (OC). There isi relationship between organizational commitments (OC) to effective teamwork (ETW), organizational commitment (OC) gives $97.8 \%$ on effective teamwork (ETW). The result shows that organizational commitment (OC) as a mediator variable is able to provide a positive influence on the relationship between the two variables. The result also shows that thare are no releationship between emotional intelligence (EI) and effective teamwork (ETW) (CR: 1.96) and relationship between quality of worklife (QWL) and effective teamwork (ETW) CR:1.96).
\end{abstract}

Keywords: effective teamswork, emotional intelligence, quality of work life, organizational commitment.

\begin{abstract}
ABSTRAK
Penelitian ini bertujuan untuk mengetahui hubungan antara variabel kualitas kehidupan kerja (KKK), kecerdasan emosi (KE) dan komitmen organisasi (KO) terhadap tim kerja efektif (ETK) dan mengidentifikasi variable mana yang memberikan sumbangan terbesar terhadap efektifitas tim kerja dengan sampel sebanyak 127 karyawan Rumah Sakit Nurhidayah Bantul,Yogyakarta. Data yang diperoleh dianalisis dengan metode Structural Equation Modeling atau SEM menggunakan program Amos. Hasil penelitian menunjukkan bahwa adanya hubungan antara variable KKK dengan KO. Variabel KKK memberikan sumbangan efektif sebesar 30,5\% terhadap KO.Hasil penelitian juga menunjukkan adanya hubungan KE dengan KO, dengan sumbangan efektif sebesar 12,5\%. Terdapat hubungan antara KO dengan efektifitas tim kerja, Persentase kaitan atau hubungan antara variabel KO dan ETK, dengan sumbangan efektif sebesar 97,8\%. Hal tersebut menunjukkan bahwa variable KO sebagai variabel mediator mampu memberikan pengaruh positif terhadap suatu hubungan diantara kedua variabel. Hasil analisis data juga menunjukkan bahwa tidak ada hubungan
\end{abstract}


KE dengan ETK dengan CR=1,96. Tidak ada hubungan antara KKK dengan ETK dengan CR=1,96.

Kata kunci: kecedasan emosi (KE), komitmen organisasi (KO), kualitas kehidupan kerja (KKK), tim kerja efektif (ETK)

\section{PENDAHULUAN}

Rumah Sakit merupakan salah satu bentuk sarana kesehatan, baik yang diselenggarakan oleh pemerintah maupun masyarakat yang berfungsi untuk melakukan upaya kesehatan dasar atau kesehatan rujukan dan upaya kesehatan penunjang. Industri rumah sakit saat ini mengalami persaingan yang ketat dengan semakin mudahnya perizinan pendirian rumah sakit swasta. Lokasinya pun saat ini sudah tidak lagi mempertimbangkan jarak antar rumah sakit, sehingga persaingan sangat mengandalkan kualitas pelayanan, biaya perawatan dan tenaga medis yang ditawarkan.

Keberhasilan rumah sakit dalam menjalankan fungsinya ditandai dengan adanya mutu pelayanan prima. Pelayanan kesehatan yang bermutu adalah pelayanan kesehatan yang memuaskan pemakai jasa pelayanan serta yang diselenggarakan sesuai dengan standard dan etika profesi. Untuk mencapai tujuan tersebut tentunya diperlukan kerjasama yang efektif, baik dari manajemen maupun karyawan. Kesuksesan sebuah organisasi sangat ditentukan oleh cara kerja anggota organisasi dalam berproses dan menentukan output kerja yang dihasilkan. Kerjasama di dalam suatu organisasi merupakan bagian penting dari tugas individu dalam menjalankan fungsinya sebagai seorang pekerja.

Salah satu organisasi yang sedang mengalami permasalahan terkait dengan tim kerja adalah X. Berdasarkan wawancara awal oleh peneliti terhadap beberapa karyawan, masih terdapat beberapa masalah yang berkaitan dengan tim kerja efektif. Sebenarnya visi dan misi organisasi sudah diketahui oleh para karyawan, mereka juga mengetahui tugastugasnya dalam sebuah tim kerja. Hanya saja iklim kerja yang ada dirasa masih kurang nyaman. Saat ini para karyawan sulit untuk melakukan kerjasama secara efektif, beberapa alasan yang disampaikan diantaranya mereka para junior merasa sulit melakukan komunikasi yang baik dengan senior, mereka merasa masih ada jarak dalam menyampaikan pendapat, sehingga ada partisipasi beberapa karyawan yang masih rendah dalam setiap diskusi maupun memecahkan beberapa masalah dalam tim kerjanya. Hubungan antar karyawan dirasa masih bersifat formalitas, terbatas hubungan kerja, komunikasi yang terjalin juga masih terkelompok, mereka kurang terbuka satu sama lainnya, sehingga seringkali terjadi kesalahpahaman, ketidaksamaan persepsi. Hal tersebut berdampak terhadap suasana kerja dan tim kerja di rumah sakit $X$. Tim kerja dirasakan belum efektif atau kurang maksimal untuk mendukung pelayanan pada pasien dan pelanggan.

Guna mengetahui, memperbaiki dan meningkatkan kemampuan karyawan untuk kerja tim maka perlu dan penting untuk ditelaah lebih jauh hal-hal yang mendasari munculnya permasalahan tersebut. Penelitian ini menggunakan 2 faktor yang diprediksi berpengaruh terhadap tim kerja efektif yaitu faktor dari individu ialah kecerdasan emosi, faktor dari dalam organisasi sendiri ialah kualitas kehidupan kerja karyawan dan faktor komitmen organisasi yaitu faktor yang berasal dari individu dan organisasi sebagai mediator yang 
berpengaruh langsung kepada tim kerja efektif di rumah sakit tersebut.

Tim Kerja adalah kelompok yang usahausaha individualnya menghasilkan kinerja lebih tinggi daripada jumlah masukan individual (Robbins \& Judge, 2008). Kinerja yang dicapai oleh sebuah tim lebih baik daripada kinerja perindividu disuatu organsasi. Tim kerja efektif adalah kelompok kerja yang dapat mengerjakan tugasnya dengan memenuhi persyaratan baik dari segi kualitas, kuantitas dan ketepatan waktu. (Stephanie dan Ulloa, 2004).

Tim kerja efektif sesuai dengan pendapat Kreitner \& Kinicki (2004) adalah kelompok kecil dengan keterampilan yang saling melengkapi, saling menahan diri dan bertanggung jawab untuk sebuah tujuan umum dengan memperhatikan tiga komponen yaitu kerjasama, kepercayaan dan kohesivitas. Smither, Houston \& McIntire (1996) menyebutkan bahwa tim yang efektif adalah sebuah tim yang memungkinkan anggotanya untuk bisa menghasilkan penyelesaian tugas yang lebih besar jumlahnya dibandingkan dengan hasil kerja perorangan karena hasil kerjanya merupakan hasil dari kontribusi anggota-anggota tim secara bersama-sama.

Kreitner \& Kinicki (2004) menyebutkan bahwa tim kerja efektif terdiri atas tiga aspek yaitu: kerjasama,kepercayaan, kohesivitas. Kerjasama dimaksudkan sebagai suatu usaha bersama antara orang perorangan atau kelompok manusia untuk mencapai satu atau tujuan bersama. Individu akan mengutamakan kerja sama ketika mereka dihadapkan secara sistematis untuk melaksanakan tujuan bersama. Aspek kedua yaitu kepercayaan. Kepercayaan didefinisikan sebagai tingkah laku dan intense timbal balik antara anggota organisasi. Saling memberi dan menerima merupakan aspek dari kepercayaan para anggota organisasi. Kecenderungan untuk bisa saling mempercayai tergantung pada sifat kepribadian yang memerlukan suatu rasa kerelaan secara menyeluruh untuk dapat percaya kepada hal-hal yang lainnya. Aspek ketiga yaitu kohesivitas, yaitu suatu proses yang muncul melalui perasaan dan kerelaan hati untuk bergabung menjadi satu yang meliputi perbedaan secara individual dan motivasi. Anggota dari tim yang kohesif akan saling melekatkan diri mereka dalam tim tersebut untuk selamanya. Mereka enggan untuk meninggalkan tim dan melekatkan diri menjadi satu atau menggabungkan diri dengan pengikut selanjutnya dengan alasan karena telah nyaman dengan organisasi tersebut atau karena mereka saling membutuhkan untuk bisa mencapai tujuan bersama.

Salah satu faktor yang mempengaruhi efektivitas tim kerja adalah komitmen organisasi. Mowday,Porter \& Steers (1982) menyatakan bahwa komitmen organisasi merupakan perasaan dan sikap mengenai organisasi kerja secara keseluruhan. Individu yang mempunyai komitmen organisasi yang tinggi akan merasakan apa yang dimiliki oleh organisasi merupakan apa yang dimilikinya sehingga akan meningkatkan motivasi untuk mencapainya. Individu dengan komitmen yang tinggi akan mengidentikan dirinya dengan organisasi dan memiliki komitmen untuk mencapai tujuan organisasi. Individu tersebut akan memiliki kesediaan untuk bekerja keras dalam mencapai tujuan organisasi dan tidak ingin meninggalkan organisasi (Kreitner \& Kinicki, 2004).

Greenberg dan Baron (2003) menyebutkan bahwa komitmen organisasi merupakan derajat atau tahapan yang dilalui seseorang dalam hubungannya dengan organisasi yang diikutinya. Derajat dalam komitmen dilihat sebagai satu kesatuan yang saling berkaitan, berkelanjutan dan tidak bisa dilihat secara sendirisendiri. Derajat komitmen organisasi menurut Greenberg dan Baron (2003) yaitu: Komitmen Afektif atau Affective Commitment; Komitmen Berkelanjutan atau Continuance Commitment; Komitmen Normatif atau Normative Commitment. Aspek dalam komitmen 
organisasi dilihat sebagai satu kesatuan yang saling berkaitan, berkelanjutan dan tidak bisa dilihat secara sendiri-sendiri.

Faktor lain yang mempengaruhi tim kerja efektif adalah kualitas kehidupan kerja. Menurut Robins (Kumar \& Rajaram, 2012) kualitas kehidupan kerja adalah sebuah proses organisasi merespon kebutuhan karyawan dengan pengembangan mekanisme yang ada agar karyawan dapat merancang kehidupan kerjanya di tempat kerja. Kualitas kehidupan kerja merumuskan bahwa setiap proses kebijakan yang diputuskan oleh perusahaan merupakan sebuah respon atas apa yang menjadi keinginan dan harapan karyawan mereka, hal itu diwujudkan dengan berbagi persoalan dan menyatukan pandangan mereka (perusahaan dan karyawan) ke dalam tujuan yang sama yaitu peningkatan kinerja karyawan dan perusahaan (Cummings \& Worly, 2003).

Pengertian yang dikemukakan oleh Dessler (2005) bahwa kualitas kehidupan kerja berarti keadaan yang dirasakan para karyawan untuk dapat memenuhi kebutuhan mereka dengan bekerja di organisasinya. kemampuan untuk melakukan hal itu bergantung pada apakah terdapat perlakuan yang adil dan sportif terhadap para pegawai oleh lingkungan ia bekerja.

Dampak positif dari kualitas kehidupan bekerja adalah memperbaiki kondisi bekerja (terutama dari perspektif karyawan) dan efektifitas organisasi lebih besar. situasi yang seimbang antara perusahaan dan karyawan dapat meningkatkan kepuasan kerja dan produktivitas perusahaan. Dampak positif lainnya misal rendahnya karyawan yang pindah/keluar dan dapat meningkatkan kepuasan kerja karyawan.

Delapan aspek kualitas kehidupan kerja yang dikembangkan oleh Walton (Farjad dan Sharnaz, 2013) yaitu: Kompensasi yang mencukupi dan adil, Kondisi-kondisi kerja yang aman dan sehat,Tanggung jawab sosial organisasi, Hak-hak karyawan, Kesempatan untuk mengembangkan dan menggunakan kapasitas manusia, Peluang untuk pertumbuhan dan mendapatkan jaminan, Integrasi sosial dalam organisasi pekerjaan, Pekerja dan ruang hidup secara keseluruhan

Faktor lain yang mempengaruhi tim kerja efektif adalah kecerdasan emosi. Goleman (2004) menyatakan bahwa kecerdasan emosional adalah suatu pengendalian diri, semangat dan ketekunan, serta kemampuan untuk memotivasi diri sendiri dan bertahan menghadapi frustasi, kesanggupan untuk mengendalikan dorongan hati dan emosi, tidak melebih-lebihkan kesenangan, mengatur suasanahati dan menjaga agar beban stres tidak melumpuhkan kemampuan berpikir, untuk membaca perasaan terdalam orang lain (empati) dan berdoa, untuk memelihara hubungan dengan sebaik-baiknya, kemampuan untuk menyelesaikan konflik serta untuk memimpin.

Kecerdasan emosi menurut Salovey (Goleman 2004) menerangkan tentang kualitaskualitas emosional yang penting bagi keberhasilan individu. Individu sangat tertarik pada konsep kecerdasan emosi dimulai peranannya dalam membesarkan dan mendidik anak, tetapi selanjutnya manusia menyadari pentingnya konsep kecerdasan emosi baik dibidang pekerjaan maupun hampir semua bidang yang mengharuskan individu untuk berhubungan dengan individu lain.

Pengertian kecerdasan emosi dalam penelitian ini berdasarkan pendapat Goleman (2004) yaitu kemampuan seseorang dalam menggunakan atau mengelola emosi baik pada diri sendiri maupun ketika berhadapan dengan orang lain, dan menggunakannya secara efektif untuk memotivasi diri dan bertahan pada tekanan, serta mengendalikan diri untuk mencapai hubungan yang produktif.

Menurut Goleman (2004), ada 5 aspek kecerdasan emosi yaitu: kesadaran diri, kendali diri, motivasi diri, empati dan kecapakan social. Kesadaran diri yaitu kemampuan individu untuk mengenali dan memahami suasana hati diri sendiri 
beserta efek yang ditimbulkan pada saat perasaan itu timbul disebut kesadaran diri. Kendali diri yaitu kemampuan individu untuk mengontrol atau mengarahkan suasana hati dan selalu melakukan pertimbangan terlebih dahulu sebelum mengambil tindakan. Motivasi diri yaitu daya dorong yang dilatarbelakangi motif individu untuk melakukan pekerjaan, baik berasal dari dalam diri individu maupun dari luar individu. Empati yaitu kemampuan untuk memahami perasaan maupun pikiran orang lain dan Kecakapan sosial yaitu kemampuan individu dalam memahami dan mengkoordinasikan keadaan emosi diri dengan perilaku yang wajar terhadap orang lain, disesuaikan dengan ketentuan etika dan norma masyarakat.

Kualitas kehidupan kerja sangat berbepengaruh terhadap kinerja karyawan dan komitmen organisasi. Penelitian Husnawati (2006) memberikan bukti bahwa aplikasi program kualitas kehidupan kerja melalui dimensi-dimensi pertumbuhan dan pengembangan partisipasi, upah dan keuntungan serta lingkungan kerja di dalam perusahaan akan berpengaruh pada peningkatan kinerja karyawan. Semakin baik aplikasi program ini maka semakin tinggi pula kinerja yang ditunjukkan. Penelitian ini juga membuktikan bahwa aplikasi program kualitas kehidupan kerja juga berpengaruh terhadap peningkatan komitmen organisasional dan selanjutnya berpengaruh pada kinerja karyawan. Semakin kuat komitmen organisasional maka semakin baik pula kinerja karyawan yang bersangkutan. Aplikasi program kualitas kehidupan kerja juga berpengaruh pada karyawan. Semakin tinggi tingkat kepuasan yang dirasakan terhadap perusahaan, maka semakin baik pula kinerja ditunjukkan oleh karyawan.

Kualitas kehidupan kerja merupakan masalah utama yang patut mendapat perhatian organisasi (Lewis dkk, 2001). Kualitas kehidupan kerja dipandang mampu untuk meningkatkan peran serta dan sumbangan para anggota atau karyawan terhadap organisasi.
Penelitian terdahulu menunjukkan bahwa kualitas kehidupan kerja mempunyai pengaruh positif dan signifikan terhadap kinerja dan menumbuhkan keinginan para karyawan untuk tetap tinggal dalam organisasi. Penelitian juga menunjukkan adanya hubungan positif antara praktek kualitas kehidupan kerja dengan kinerja karyawan (Elmuti dan Yunus, 1997).

Individu merupakan salah satu faktor yang mempengaruhi kinerja organisasi. Mayer, Gaschke dan Tesser (Abraham, 2004) menjelaskan bahwa secara konseptual kecerdasan emosi secara efektif melengkapi kecerdasan kognitif untuk memprediksi kinerja yang tinggi melalui dimensi-dimensinya seperti penilaian diri, pengaturan diri, motivasi, empati dan keterampilan sosial.

Penelitian yang dilakukan Kumar \& Rajaram (2012) juga menunjukkan bahwa kemampuan untuk memahami lingkungan dan dengan berbagai perubahan sangatlah penting di era dinamis, dimana kualitas kehidupan kerja tergantung dengan berbagai faktor. Kecerdasan emosional seseorang memiliki korelasi positif dengan kualitas kehidupan kerja, yaitu bagaimana para karyawan memandang, menyesuaikam diri dengan stress atau permasalahan yang muncul secara unik dan berbeda-beda.

Hasil studi dari Stephanie dan Uloa (2004) menyatakan bahwa ada beberapa hal yang berkaitan dengan sikap individu yang memberikan efek positif terhadap terbentuknya kerja sama yang efektif yaitu ketika individu atau anggota kerja mau melakukan komunikasi yang baik, memiliki kohesivitas yang tinngi, memiliki tujuan yang jelas dan sama, paham dan mengerti mengenai peran nya. Dalam studi ini juga dijelaskan bahwa Efektifitas tim kerja adalah bagaimana dan sejauhmana tim kerja dapat mengerjakan tugasnya dengan memenuhi persyaratan baik dari segi kualitas, kuantitas dan ketepatan waktu.

Berdasarkan hal tersebut maka kehidupan kerja yang berkualitas dan 
kecerdasan emosi yang dimiliki individu akan memungkinkan individu untuk mampu mengelola emosinya dengan baik, sehingga terekspresikan secara tepat dan efektif, yang pada akhirnya akan membawa individu mampu berkomitmen terhadap organisasinya untuk melakukan kerjasama dalam tim demi menuju sasaran dan tujuan organisasi yang efisien dan efektif.

\section{HASIL DAN PEMBAHASAN}

Berdasarkan uji normalitas Asumsi normalitas data harus dipenuhi agar data dapat diolah lebih lanjut untuk pemodelan SEM. Pengujian normalitas secara univariate ini adalah dengan mengamati nilai skewness data yang digunakan, apabila nilai CR pada skewness data

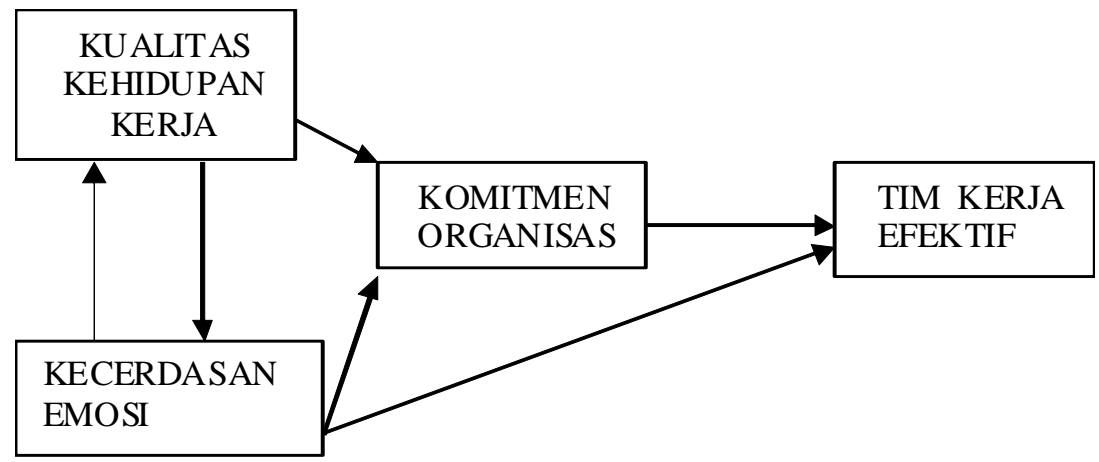

Gambar 1. model peran kualitas kehidupan kerja dan kecerdasan emosi dengan komitmen organisasi sebagai mediator terhadap tim kerja efektif.

\section{METODE PENELITIAN}

Metode yang digunakan untuk pengumpulan data dalam peneltian ini adalah skala yang masingmasing mengukur satu variable. Skala kerja tim berjumlah 15 item. Skala komitmen organisasi berjumlah 15 item. Skala kualitas kehidupan kerja berjumlah 32 item.

Skala kecerdasan emosi berjumlah 25 item. keempat skala tersebut menggunakan metode Rating yang dijumlahkan (Methode of summated rating) dari Likert dengan lima alternative jawaban pada masing-masing butir Skala yaitu: SS (sangat sesuai), S (sesuai), AS (agak sesuai), TS (tidak sesuai), STS (sangat tidak sesuai). Subjek penelitian yang digunakan dalam penelitian ini adalah karyawan non medis yang berjumlah 140 orang yang bekerja di Pelayanan Medik, Layanan Penunjang Medik dan Pelayanan dan Penunjang Umum. Data dianalisis dengan metode Structural Equation Modeling atau SEM menggunakan program Amos. (lampiran ) berada diantara rentang antara $+2,58$ pada tingkat signifikansi 0,05 , maka data penelitian yang digunakan dapat dikatakan normal.

Sebelum melakukan analisis model struktural dan model measurement, perlu dilihat apakah model secara keseluruhan merepresentasikan keseluruhan hubungan sebab akibat. Terdapat tiga tipe goodness-of-fit yang biasa digunakan yaitu Absolut Fit Measures, Incremental Fit Measures, dan Parsimony Fit Measure. Absolut Fit Measure diwakili oleh $\div 2$ dan significant level, Root Mean Square Error of Approximation (RMSEA), Goodness-of-fit Index (GFI) dan Adjusted Goodness-of-Fit Index (AGFI). Incremental Fit Measures menggunakan pengukuran Tucker-Lewis Index (TLI). Terakhir, Parsimonious Fit Measures menggunakan pengukuran Comparative Fit Index (CFI). Berdasarkan hasil uji kesesuaian model akan disajikan pada gambar 2 . 


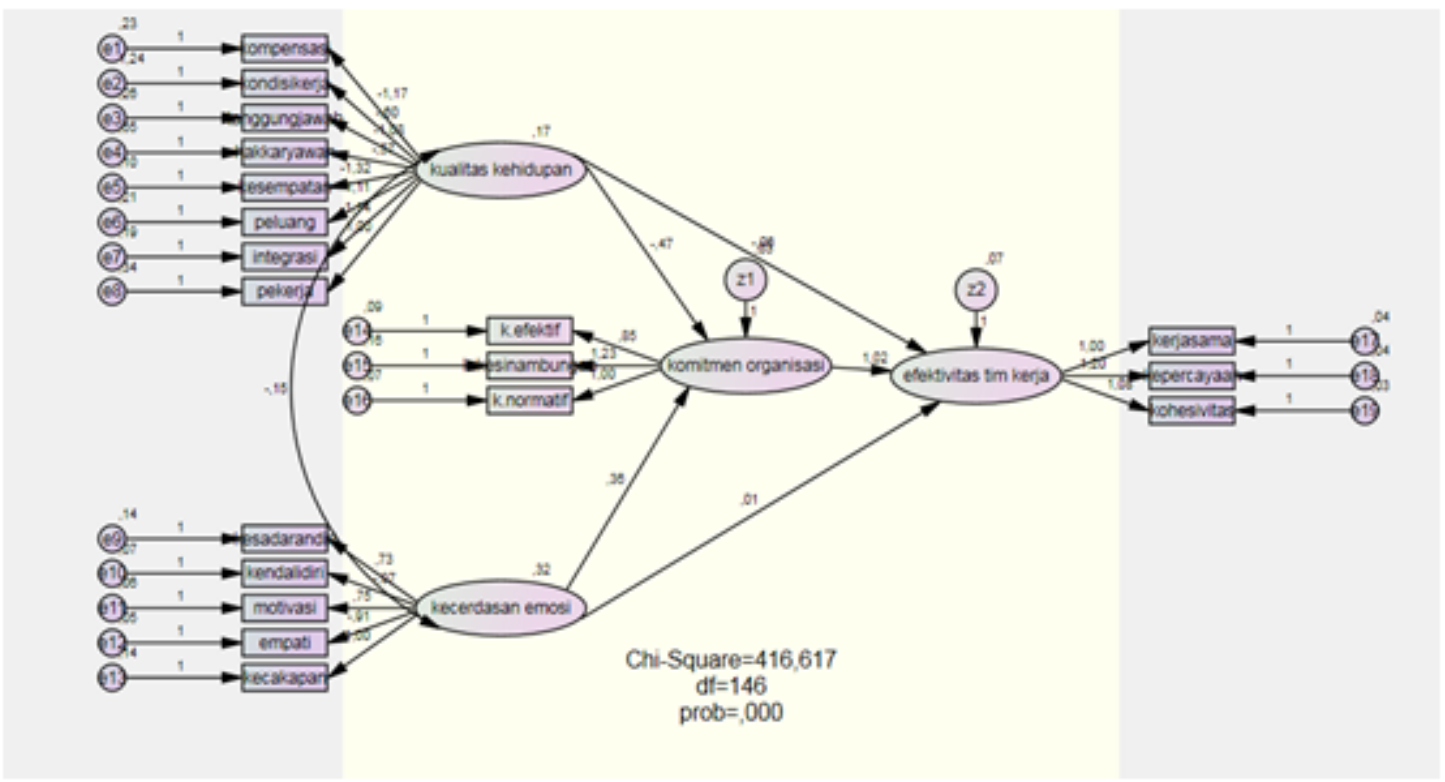

Gambar 2. Full Model Struktural

Gambar 2 menunjukkan pengembangan model struktural. Hasil uji menunjukkan bahwa model tidak fit, yang ditunjukkan dengan nilai chisquares 416,617 dengan probabilitas 0.000. Demikian pula kriteria fit lainnya AGFI,CFI, dan TLI nilainya di bawah yang direkomendasikan yaitu e” 0.90 dan RMSEA di atas nilai yang direkomendasikan yaitu d” 0.08. (tabel 17).

Untuk memperbaiki model fit, maka dilakukan modification indices. Hasil output revisi model ditunjukkan pada gambar 2. Dari gambar 2 diketahui bahwa Berdasarkan hasil pengujian modification indices, diketahui dari kriteria yang ada diantaranya rata-rata berada pada kondisi baik (Fit). Dengan hasil ini maka secara keseluruhan dapat dikatakan bahwa model penelitian memiliki tingkat goodness of fit yang baik.

Tabel 1: Hasil pengujian goodness of fit

\begin{tabular}{lccc}
\hline Goodness of fit index & Kriteria & Cut of value & Keterangan \\
\hline Chi-square & Harus kecil & 416,617 & Tidak fit \\
Significant Probability & $=0,05$ & 0,000 & Tidak fit \\
RMSE A & $=0,08$ & 0,121 & Tidak fit \\
GFI & 0 sampai 1 & 0,773 & Fit \\
AGFI & $=0,90$ & 0,704 & Tidak fit \\
CMIN / DF & $=2,00$ & 2,854 & Tidak Fit \\
TLI & $=0,90$ & 0,840 & Tidak Fit \\
CFI & $=0,90$ & 0,863 & Tidak Fit \\
NFI & $=0,90$ & 0,806 & Tidak Fit \\
CFI & $=0,90$ & 0,863 & Tidak Fit \\
RFI & $=0,90$ & 0,773 & Tidak Fit \\
IFI & $=0,90$ & 0,865 & Tidak Fit \\
PRATIO & 0 sampai 1 & 0,854 & fit \\
PNFI & 0 sampai 1 & 0,688 & fit \\
PCFI & 0 sampai 1 & 0,737 & fit \\
ECFI & Diantara saturated & 4,005 & fit \\
& dan independent & & \\
\hline
\end{tabular}


Tabel 2: Hasil pengujian goodness of fit modification indices

\begin{tabular}{lccc}
\hline Goodness of fit index & Kriteria & Cut of value & Keterangan \\
\hline Chi-square & Harus kecil & 232.789 & Tidak fit \\
Significant Probability & $=0,05$ & 0.000 & Tidak fit \\
RMSEA & $=0,08$ & 0.074 & fit \\
GFI & 0 sampai 1 & 0.835 & Fit \\
AGFI & $=0,90$ & 0.772 & Tidak fit \\
CMIN / DF & $=2,00$ & 1.687 & Fit \\
TLI & $=0,90$ & 0.941 & Fit \\
CFI & $=0,90$ & 0.952 & Fit \\
NFI & $=0,90$ & 0.892 & Tidak Fit \\
CFI & $=0,90$ & 0.952 & Fit \\
RFI & $=0,90$ & 0.866 & Tidak Fit \\
IFI & $=0,90$ & 0.953 & Fit \\
PRATIO & 0 sampai 1 & 0.807 & fit \\
PNFI & 0 sampai 1 & 0.719 & fit \\
PCFI & 0 sampai 1 & 0.768 & fit \\
ECFI & Diantara & 2.673 & fit \\
& saturated dan & & \\
& independent & & \\
\hline
\end{tabular}

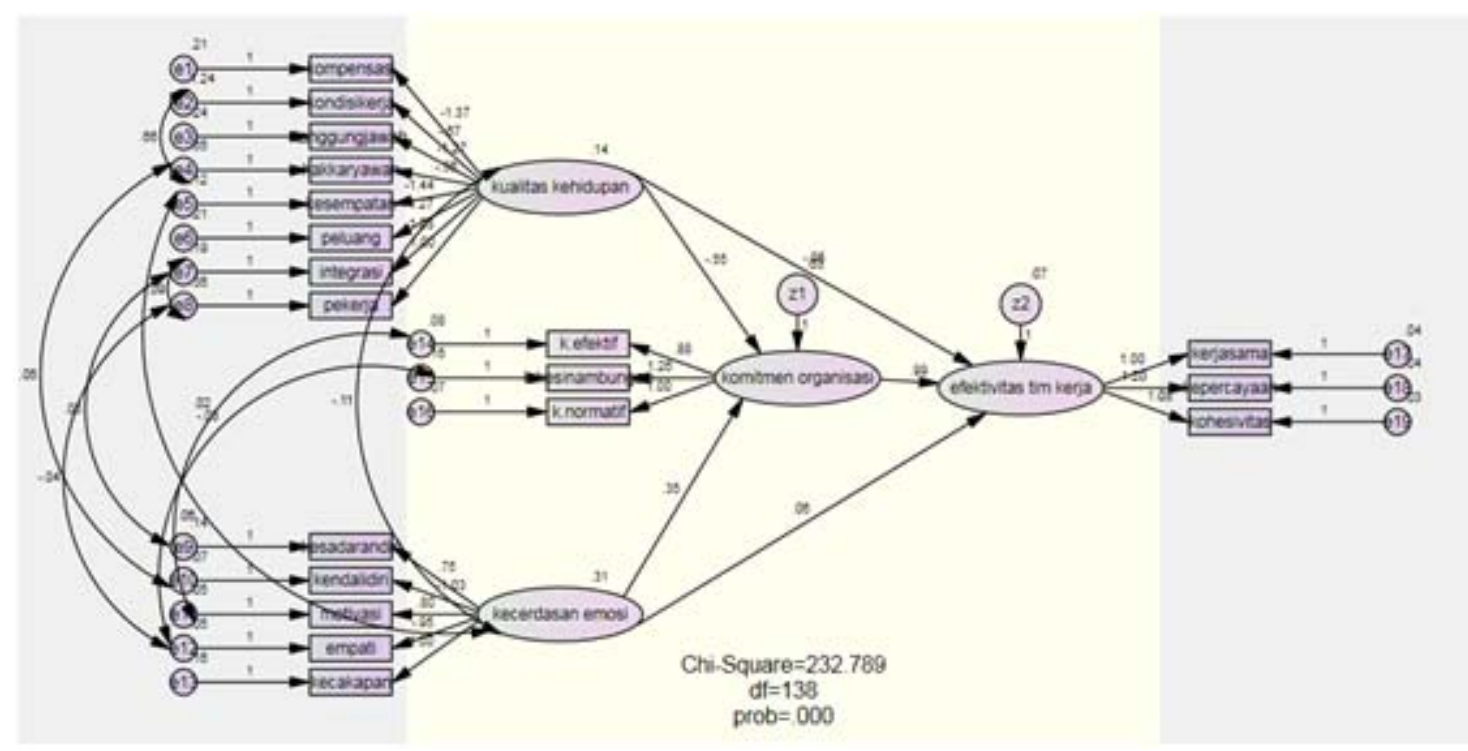

Gambar 3. Full Model Struktural Setelah Revisi

Berdasarkan hasil analisis data, diketahui bahwa ada pengaruh kualitas kehidupan kerja terhadap komitmen organisasi dengan nilai $\mathrm{CR}=$ 4,626 $(\mathrm{P}<0,00)$. Variabel kualitas kehidupan kerja memberikan sumbangan efektif sebesar 30,5\% terhadap komitmen organisasi. Komitmen organisasi yang terbentuk adalah komitmen afektif yang bersifat intrinsik yaitu karyawan menjunjung tinggi nilai-nilai yang telah disepakati. Adanya persetujuan atas tujuan-tujuan dan nilainilai yang ada karena membenarkan apa yang dilakukan organisasi untuk mencapai misinya merupakan alasan dari munculnya keinginan karyawan untuk tetap melibatkan diri dan tinggal dalam organisasi. Tabel 3 di bawah ini menjelaskan hasil analisis regresi. 
Tabel.3 Hasil Analisis Regresi

\begin{tabular}{|c|c|c|c|c|c|c|c|}
\hline Variabel & Pengaruh & Variabel & ? & r2 & C.R & $\mathbf{P}$ & Ket \\
\hline $\begin{array}{l}\text { Kualitas } \\
\text { kehidupan kerja }\end{array}$ & & $\begin{array}{l}\text { Komitmen } \\
\text { organisasi }\end{array}$ & $-0,553$ & 0,305 & 4,626 & 0,000 & sig \\
\hline $\begin{array}{l}\text { Kecerdasan } \\
\text { emosi }\end{array}$ & & $\begin{array}{l}\text { Komitmen } \\
\text { organisasi }\end{array}$ & 0,354 & 0,125 & 5,728 & 0,000 & Sig \\
\hline $\begin{array}{l}\text { Komitmen } \\
\text { organisasi }\end{array}$ & & Tim kerja efektif & 0,989 & 0,978 & 3,731 & 0,000 & sig \\
\hline $\begin{array}{l}\text { Kecerdasan } \\
\text { emosi }\end{array}$ & & Tim kerja efektif & 0,056 & 0,056 & 0,515 & 0,607 & No sig \\
\hline $\begin{array}{l}\text { Kualitas } \\
\text { kehidupan kerja }\end{array}$ & 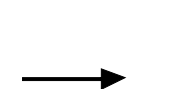 & Tim kerja efektif & $-0,054$ & 0,003 & $-0,287$ & 0,774 & No sig \\
\hline $\begin{array}{l}\text { Kecerdasan } \\
\text { emosi }\end{array}$ & $\longleftrightarrow$ & $\begin{array}{l}\text { Kualitas } \\
\text { kehidupan kerja }\end{array}$ & $-0,543$ & 0,294 & 3,879 & 0,000 & sig \\
\hline
\end{tabular}

Hal tersebut sesuai dengan penelitian yang dilakukan Husnawati (2006) yang menunjukkan hasil bahwa kualitas kehidupan kerja berpengaruh terhadap peningkatan komitmen organisasional dan selanjutnya berpengaruh pada kinerja karyawan. Semakin kuat komitmen organisasional maka semakin baik pula kinerja karyawan yang bersangkutan. Aplikasi program kualitas kehidupan kerja juga berpengaruh pada karyawan. Semakin tinggi tingkat kepuasan yang dirasakan terhadap perusahaan, maka semakin baik pula kinerja ditunjukkan oleh karyawan.

Hasil penelitian juga menunjukkan bahwa ada pengaruh kecerdasan emosi terhadap komitmen organisasi dengan nilai $\mathrm{CR}=5,728$ $(\mathrm{P}<0,000)$. Kecerdasan emosi memberikan sumbengan efektif sebesar 12,7\% terhadap komitmen organisasi. Aspek-aspek pada kecerdasan emosi seperti kesadaran diri, motivasi dan kecakapan sosial karyawan dinilai tinggi yang artinya karyawan mampu para karyawan mampu mengenali emosi diri sendiri beserta efek yang ditimbulkan pada saat perasaan itu muncul. Karyawan juga memiliki motivasi, daya dorong dari dalam diri individu maupun dari luar individu untuk melakukan pekerjaan yang baik di rumah sakit tersebut dan mau untuk memahami dan mengkoordinasikan keadaan emosi diri dengan perilaku yang wajar terhadap orang lain sehingga terbentuk komitmen organisasi yang tinggi dalam diri karyawan.

Berdasarkan hasil anaisis data diketahui bahwa komitmen organisasi mempunyai pengaruh terhadap tim kerja efektif dengan nilai $\mathrm{CR}=3,879(\mathrm{P}<0,00)$. Variabel Komitmen organisasi memberikan sumbangan efektif sebesar 97,8\% terhadap tim kerja efektif. Komitmen organisasi berhubungan langsung dengan aspek-aspek yang ada di tim kerja efektif dengan tingginya komitmen mereka terhadap organisasi, maka karyawan memiliki kemauan untuk menjunjung tinggi nilai-nilai yang telah disepakati. Karyawan dengan komitmen organisasi yang tinggi akan bersedia berkorban demi kepentingan organisasi (Greenberg dan Baron, 2003). Karyawan yang mempunyai tingkat komitmen tinggi pada organisasi memiliki kemungkinan yang lebih besar untuk tidak meninggalkan organisasi, karyawan yang memiliki komitmen yang tinggi menunjukkan keinginan untuk memberikan tenaga dan tanggungjawab yang lebih dalam mendukung keberhasilan dan 
kesejahteraan organisasi di tempat kerjanya. Karyawan mau melakukan kerjasama, saling percaya dan saling membantu antar satu dengan lainnya dalam sebuah tim kerja. Adanya persetujuan atas tujuan-tujuan dan nilai-nilai yang ada karena membenarkan apa yang dilakukan organisasi untuk mencapai misinya merupakan alasan dari munculnya keinginan karyawan untuk tetap melibatkan diri dan tinggal dalam organisasi.

Hasil penelitian juga menunjukkan bahwa kualitas kehidupan kerja tidak berpengaruh secara langsung terhadap tim kerja efektif dengan nilai $C R=-0,287(\mathrm{P}=0,742)$. Apabila dilihat dari rerata aspek kualitas kehidupan kerja bahwa masih ada tuntutan yang bersifat ekstrinsik yaitu kompensasi dan ruang hidup pekerja secara keseluruhan, mereka merasa kompensasi atau gaji yang diterima belum sesuai dengan kebutuhan mereka, waktu yang diberikan juga belum cukup untuk karyawan bersama keluarga dan lingkungan sosialnya sehingga tuntutan-tuntutan ekstrinsik yang masih rendah inilah yang belum mendukung terhadap tim kerja efektif secara langsung.

Dari hasil analisis data juga diketahui bahwa kecerdasan emosi juga tidak berpengaruh langsung terhadap tim kerja efektif dengan nilai $\mathrm{CR}=0,515(\mathrm{P}=0,607)$. Berdasarkan hasil waancara, didapatkan bahwa aspek empati dan kendali diri pada karyawan sejauh ini masih rendah padahal, padahal kedua aspek tersebut sangat berperan penting dalam sebuah tim kerja efektif untuk mau bekerjasama, mau saling percaya dan kohesif dalam bekerja.

Hasil analisis data menunjukkan adanya hubungan timbal balik antara kecerdasa emosi dengan kualitas kehidupan kerja dengan nilai $\mathrm{CR}=3,879(\mathrm{P}<0,00)$. Hal ini berarti bahwa kecerdasan emosi dan kualitas kehidupan kerja juga terbukti saling mempengaruhi. Kecerdasan emosi faktor yang berasal murni dari pribadi karyawan masing-masing sedangkan kualitas kehidupan kerja faktor dari lingkungan organisasi itu sendiri yang dipersepsi berbeda-beda oleh masing-masing karyawan. Hasil ini sejalan dengan Penelitian yang dilakukan Kumar \& Rajaram (2012) yang menunjukkan bahwa kemampuan untukmemahami lingkungan dan dengan berbagai perubahan sangatlah penting di era dinamis, dimana kualitas kehidupan kerja tergantung dengan berbagai faktor. Kecerdasan emosional seseorang memiliki korelasi positif dengan kualitas kehidupan kerja, yaitu bagaimana para karyawan memandang, menyesuaikan diri dengan stress atau permasalahan yang muncul secara unik dan berbeda-beda.

\section{SIMPULAN}

Berdasarkan temuan tersebut dapat diketahui bahwa pada model persamaan ini hanya variabel komitmen organisasi yang dapat menjadi prediktor terhadap tim kerja efektif, sedangkan kualitas kehidupan kerja dan kecerdasan emosi dapat dijadikan prediktor untuk komitmen organisasinya. Berdasarkan hasil pada model persamaan ini diketahui bahwa tidak ada pengaruh langsung kecerdasan emosi dan kualitas kehidupan kerja terhadap tim kerja efektif. Penelitian ini diharapkan dapat memberikan penjelasan tentang pengaruh setiap variabel yaitu kualitas kehidupan kerja,kecerdasan emosi,komitmen organisasi terhadap tim kerja efektif.

\section{DAFTAR PUSTAKA}

Abraham, R. 2004. Emotional Competence as Antecedent to Perfomance; A Contingency Framework. Genetic, Social, and General Psychology Monographs, 130 (2), 117-143

Dessler, G. 2005. Manajemen Sumber Daya Manusia. Alih bahasa: Eli Tanya. Penyunting Bahasa: Budi Supriyanto. Jakarta: Indeks. 
Elmuti, D. \& Yunus, K. 1997 “An Investigation into Effects of ISO 9000 on Participants' Attitudes and Job Performance". Production and Inventory Management Journal. Second Quarter

Greenberg, J. \& Baron, R. A. 2003. Behavior in organization. Massac Husetts: Allyn \& Baron.

Goleman, D. 2004. Emotional Intellegence. Kecerdasan emosi mengapa EI lebih penting daripada IQ. Alih bahasa : T. Hermaya, cetakan ke-14, Jakarta : Gramedia Pustaka umum

Husnawati, A. 2006. Analisis pengaruh kualitas kehidupan kerja terhadap kinerja karyawan dengan komitmen dan kepuasan kerja sebagai intervening variabel, Tesis. Semarang : Magister Manajemen UNDIP

Kreitner, R \& Kinicki, A. 2004. Organitational Behavior. $5^{\text {th }}$ Ed. New York : Irwin Mc Graw-Hill.

Kumar, S.J. \& Vidya, R.I. 2012. Emotional Intelligence and QWL- Life Among Employess In The Educational Instituitions. SIES Journal Of Management. Volume 8. No 2:21-24

Lewis, D. \& Kevin, B.\& Paul. K. \& Lynne. L, and Erin. T. 2001. "Extrinsic and Intrinsic Determinants of Quality of Work Life". International Journal of health Care Quality Assurance Incorporating Leadership in Health Service. -Vol. 14. p.915
Mowday, R. \& Porter, L.W. \& Steers, R.M. 1982. Employee Organization Linkages: The Psychology Of Commitment, Absenteeism and turnover. New York : Academic Press

Robbins,S.P. dan Judge, T.A 2008.Perilaku Organisasi Edisi ke-12, Jakarta: Salemba Empat.

Stephanie, G.A. \& Uloa, R.B.C. 2004. Attitude Toward Teamwork and effective teaming. Emerald Group Publishing. Team Perfomance Management Volume 10. 145-148

Sharnaz, V. \& Farjad, R.H 2013. Study Of Relathionship OfQWLAnd Organizational Commitment. Interdisciplinary Journal of Contemporary Research In Business. Volume 4. No 9, 449-451

Smither,R.D. Houston, J.M \& McIntire, S.D. 1996. “Organization Development: Strategies for Changing Environment”,.HarperCollins College Publishers, New York. 
